\title{
Down-regulation of transforming growth factor beta-2 expression is associated with the reduction of cyclosporin induced gingival overgrowth in rats treated with roxithromycin: an experimental study
}

\author{
Simone Aparecida Probst Condé*1, Marcus Gomes Bastos², \\ Beatriz Julião Vieira ${ }^{3}$ and Fernando Monteiro Aarestrup ${ }^{4}$
}

Address: ${ }^{1}$ Post-graduate Program in Health, Federal University of Juiz de Fora/UFJF - Juiz de Fora/Brazil, Dom André Arcoverde Foundation, Department of Clinical Dental - Valença/Brazil, ${ }^{2}$ Department of Nephrology, NIEPEN Institute, IMEPEN Foundation, Federal University of Juiz de Fora/UFJF- Juiz de Fora/Brazil, ${ }^{3}$ Center of Biology Reprodution, Laboratory of Immunopathology and Experimental Pathology, Federal University of Juiz de Fora - Juiz de Fora/Brazil and ${ }^{4}$ Center of Biology Reprodution, Laboratory of Immunopathology and Experimental Pathology, Federal University of Juiz de Fora - UFJF, Suprema Instituition, Faculty of Medicine, Department of Semiology - Juiz de For a/Brazil

Email: Simone Aparecida Probst Condé* - simoneprobst@ibest.com.br; Marcus Gomes Bastos - marcusgb@terra.com.br; Beatriz Julião Vieira - fmaarestrup@hotmail.com; Fernando Monteiro Aarestrup - fmaarestrup@ hotmail.com

* Corresponding author

Published: 8 December 2009

BMC Oral Health 2009, 9:33 doi:10.1186/1472-6831-9-33
Received: 28 January 2008

Accepted: 8 December 2009

This article is available from: http://www.biomedcentral.com/I472-683I/9/33

(C) 2009 Condé et al; licensee BioMed Central Ltd.

This is an Open Access article distributed under the terms of the Creative Commons Attribution License (http://creativecommons.org/licenses/by/2.0), which permits unrestricted use, distribution, and reproduction in any medium, provided the original work is properly cited.

\begin{abstract}
Background: Gingival overgrowth (GO) is a common side effect of the chronic use of cyclosporine (CsA), an immunosuppressant widely used to prevent rejection in transplant patients. Recent studies have reported elevated levels of specific cytokines in gingival overgrowth tissue, particularly TGF-beta, suggesting that this growth factor plays a role in the accumulation of extracellular matrix materials. The effectiveness of azithromycin, a macrolide antibiotic, in the regression of this undesirable side effect has also been demonstrated.

Methods: In this study, we created an experimental model for assessing the therapeutic effect of roxithromycin in GO and the expression of transforming growth factor beta (TGF-beta2) through immunohistochemistry. We used four groups of rats totaling 32 individuals. GO was induced during five weeks and drug treatment was given on the 6th week as follows: group I received saline; group 2 received CsA and was treated with saline on the 6th week; group 3 received CsA and, on the 6th week, ampicilin; and group 4 received CsA during 5 weeks and, on the 6th week, was treated with roxithromycin.
\end{abstract}

Results: The results demonstrated that roxithromycin treatment was effective in reducing cyclosporine-induced GO in rats. Both epithelial and connective tissue showed a decrease in thickness and a significant reduction in TGF-beta2 expression, with a lower number of fibroblasts, reduction in fibrotic areas and decrease in inflammatory infiltrate.

Conclusion: The present data suggest that the down-regulation of TGF-beta2 expression may be an important mechanism of action by which roxithromycin inhibits $\mathrm{GO}$. 


\section{Background}

Gingival overgrowth (GO) is a common side effect of certain drugs, such as phenytoin, calcium channel blockers and cyclosporin $[1,2]$.

Cyclosporine (CsA) has been widely used to prevent organ transplant rejection and to treat various immunodiseases [2]. It selectively suppresses helper T-cell function and modulates the network of inflammatory cytokines. However, CsA is associated with several adverse effects, such as nephrotoxicity, hepatotoxicity, hirsutism and gingival overgrowth $(\mathrm{GO})[1,3,4]$. The average prevalence of dentate transplant patients who develop cyclosporine induced GO is around 30\%, with variation between 10 and $85 \%$ [5-9]. When associated with other medication, such as calcium channel blocker antihypertensives, this prevalence increases, as does the gravity of the complication, and, consequently, the risk [10-13].

Fibrosis, one of the most important finding in GO, is the result of a variety of biochemical signals from many cell types including inflammatory cells and fibroblasts, which stimulate fibroblast proliferation and extracellular matrix production [14]. The transforming growth factor beta (TGF-beta) is a multifunctional family of cytokines present in this pathway and there are three mammalian isoforms of TGF-beta (TGF- beta1, TGF-beta2 and TGFbeta3), which are structurally similar [15]. Increased TGFbeta1 levels have been associated in cyclosporin-induced renal fibrosis [16]. Most of the studies argue in favor of TGF-beta1 in the CsA-induced gingival overgrowth. However a few number of studies investigated the expression of TGF-beta 2 in this pathological condition $[15,17]$. TGFbeta2 is considered an immunosuppressive cytokine modulated by cyclosporine that plays a central role during the formation of fibrosis and inflammatory reaction [1820]. Recently, it was demonstrated that roxithromycin has an inhibitory effect on the production of TGF- $\beta$ beta by human mesangial cells, and may be efficient in the treatment of glomerulosclerosis [21]. Therefore, this macrolide antibiotic with similar characteristics of azithromycin, is known to have anti-inflammatory, immunomodulatory and tissue reparative effects besides its bacteriostatic activity may be a therapeutic alternative in the treatment of gingival overgrowth. Recently, we published a study with interesting results in renal transplanted patients in which the gingival overgrowth was reduced after roxithromycin treatment [22]. In the present study we investigated the effect of roxithromycin on GO in rats treated with cyclosporine. Our findings indicate that roxithromycin reduces GO and down-regulates TGFbeta2 expression in gingival tissues.

\section{Methods}

Thirty-two 6-week-old male Wistar rats (Rattus novergicus albinun), weighing 100 to $150 \mathrm{~g}$. were randomly selected and divided equally into four groups of eight animals each. The control rats (group 1) were daily injected subcutaneously with saline. The experimental rats (group 2) were treated with CsA injected subcutaneously in a daily dose of $10 \mathrm{mg} / \mathrm{kg}$ for six weeks and, at the beginning of the 6 th week, they were injected subcutaneously with saline. Group 3 was similar to group 2, but in the last week it was treated with $50 \mathrm{mg} / \mathrm{kg}$ ampicillin (an antibiotic widely used in periodontal infections) via gastric feeding. In group 4, the animals received CsA daily for 6 weeks and in the last week they were treated with $40 \mathrm{mg} / \mathrm{kg}$ roxithromycin by gastric feeding. The rats were weighed weekly and the dosage was adjusted accordingly. Diet and drinking water were given ad libitum during the experiment.

\section{Macroscopy analysis}

At the end of the experimental period, all the animals were sacrificed by means of an overdose of anesthesia (Kensol $^{\circledast}-10 \mathrm{mg} / \mathrm{kg}$ and Vetanarcol ${ }^{\oplus}-90 \mathrm{mg} / \mathrm{kg}$ ). To investigate gingival alterations over time, stone models were made from silicone impressions of the maxillary anterior region. The higher buccal-lingual width and mesio-distal width of the anterior segment of the maxilla were measured using a digital caliper.

\section{Histopathology and histomorphometry}

All gingival samples obtained were fixed in $10 \%$ buffered formalin ( $\mathrm{pH} 7$ ) for at least 24 hours. After fixation, the samples were gradually dehydrated in increasing concentrations of ethanol ( $70 \%$ to $100 \%)$, cleared in xylene, soaked and embedded in paraffin, according to routine histological methods.

The paraffin-embedded fragments were cut with an "820" Spence microtome and $4 \mu \mathrm{m}$ thick sections were obtained. All gingival samples were included in paraffin with the same orientation. The sections analysed always showed the epithelium, the connective and muscular tissue. The histometry measurements were performed since the ephitelium until the muscular tissue. The histological slides were kept in an incubator to dry, and then the sections were stained with hematoxylin and eosin for histological analysis. Histomorphometry was performed using images captured and evaluated by a computerized Axion Vision (Zeiss, Berlin, Germany) image capture system. Images were captured from four randomly chosen microscopic fields for each histological slide, using the digital

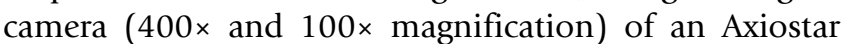
Plus microscope (Zeiss, Berlin, Germany) and the number of TGF-betapositive cells were counted.

The images were stored and submitted to a count of inflammatory cells and of all fibroblast-like cells. Linear measurements were made to obtain the higher diameter of epithelial and gingival connective tissue, using digital marking. 


\section{Immunohistochemistry}

Paraffin sections ( $4 \mu \mathrm{m}$ of thick) of formalin-fixed tissue were obtained at varying depths from each tissue block. The presence of TGF-beta 2 protein in the gingival samples was investigated in paraffin sections by using the avidinbiotin-peroxidase complex procedure (ABC) with an additional step for antigen retrieval with a retrieval solution (Dakopatts, Copenhagen, Denmark). In brief, the sections were incubated with polyclonal rabbit anti-TGFbeta2 antibody diluted $1 / 20$ and incubated for one hour at room temperature (Santa Cruz, Santa Cruz, USA) followed by a goat anti-rabbit IgG biotinylated antibody (Dakopatts, Copenhagen, Denmark). Controls for the ABC procedure were performed by replacing anti-TGFbeta2 antibody with normal rabbit serum, or by omitting the anti-TGF-beta2 antibody. The sections were analyzed via light microscopy, and photomicrographs were taken with an Axiostar Zeiss microscope (Zeiss, Germany). The number of the TGF-beta 2 immunoreactive cells by microscopic field (400 $\times$ magnification) was counted in connective tissue.

\section{Statistical analysis}

Data were expressed as means and standard deviation. ANOVA was used for statistical evaluation and the Bonfer- roni post-hoc test was used after ANOVA. The gingival mucosa width, the number of inflammatory cells, all fibroblast-like cells and TGF-beta2 immunoreactive cells were compared between groups by using the Student's $t$ test. The significance level adopted was $p<0.05$.

The manuscript has been performed with the approval of ethics committee in experimental research on animals by Federal University of Juiz de Fora/Brazil (protocol $n^{\circ} 039 /$ 2005).

\section{Results}

All cyclosporine treated rats presented GO that was evident in all gingival localizations. Graphic 1 shows macroscopic measurements of the buccal-lingual width and mesio-distal width $(\mathrm{p}<0.05)$. The macroscopic analysis revealed a significant reduction of the buccal-lingual width and mesio-distal width in the roxithromycin treated rats (group 4) when compared with group 2 and group 3 (graphic 1) ( $\mathrm{p}<0.05)$. The histopathological analysis revealed that $\mathrm{GO}$ was a result of the enlargement of epithelial and connective tissues (figures 1A, 1B, 1C, 1D). A moderate acanthosis was observed in animals from groups 2, 3 and 4. No statistical differences were observed when compared the thickness of the epithelium detected

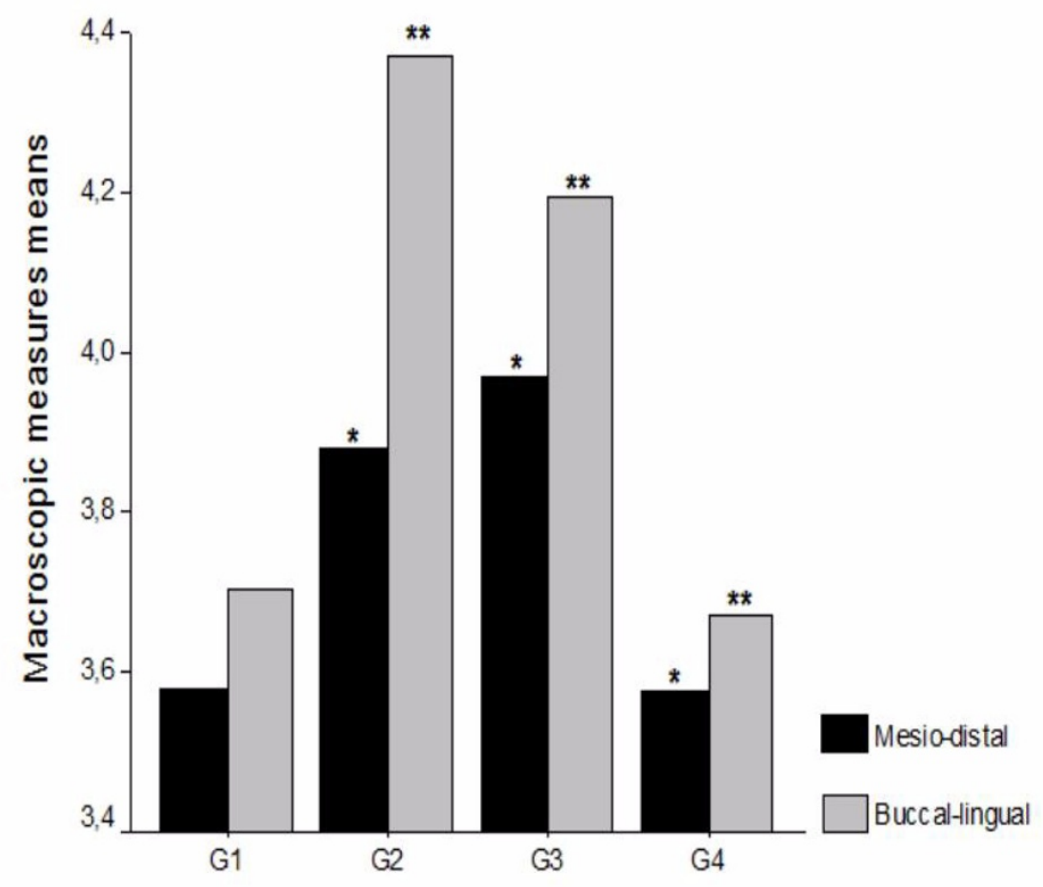

Figure I

Macroscopic measurements of buccal-lingual and mesio-distal maxillary regions. Results expressed as mean and the level of significance for statistical analyse was $\mathrm{p}<0.05$. GI ( $\mathrm{n}=8$ animals $)$ - negative control group - administration of saline solution. $\mathrm{G} 2$ ( $\mathrm{n}=8$ animals) - positive control group - administration of CsA + saline. G3 ( $n=8$ animals) - positive control group- - administration of CsA + AMP. G4 ( $n=8$ animals) - treated group - administration of CsA + ROX. 

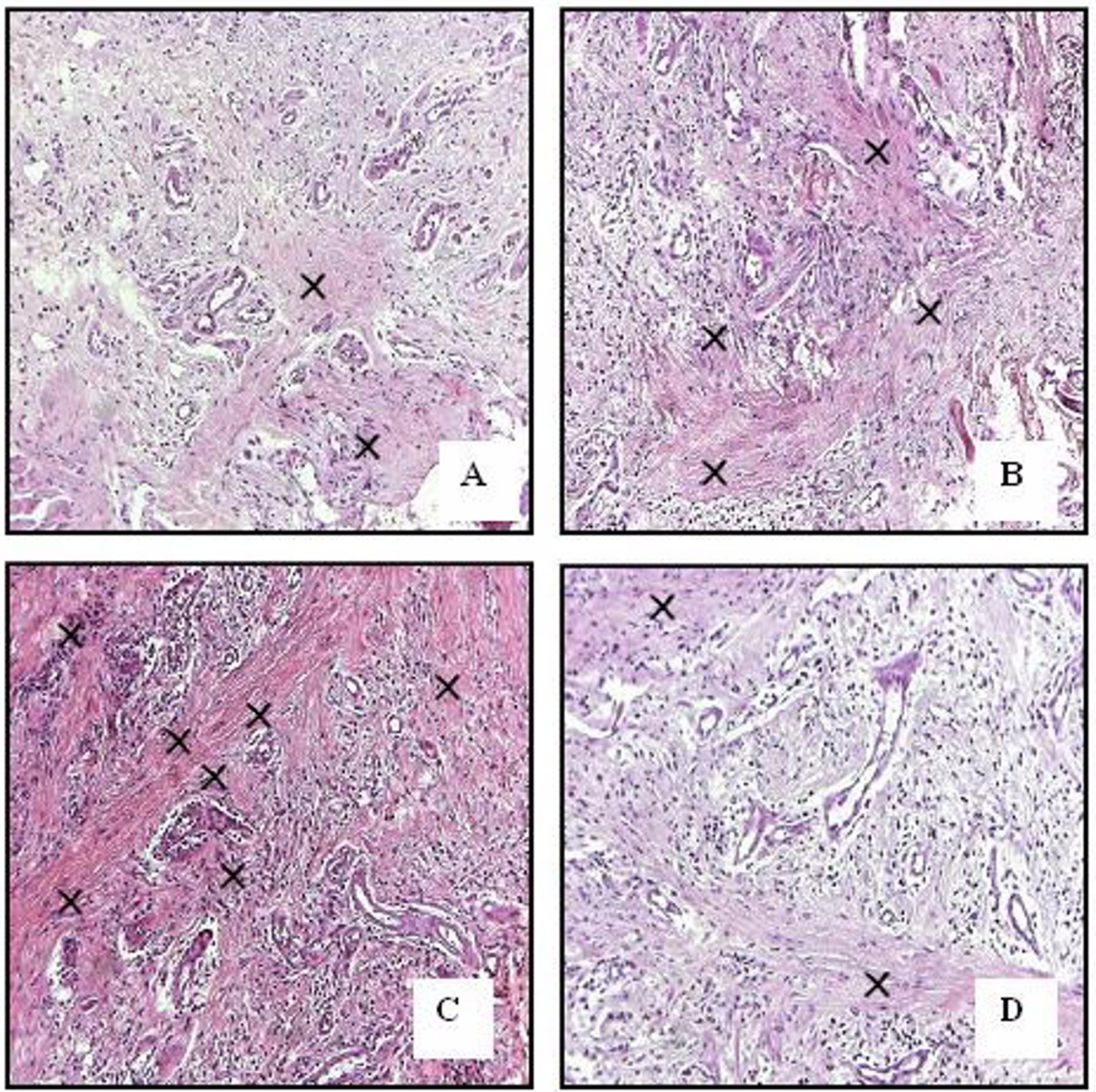

Figure 2

Representative microscopic fields. A: Normal connective tissue in group I (negative control); B-C: Extensive fibrosis in groups 2 and 3 (positive controls); D: Few areas with fibrosis in group 4 (treated group). Original magnificance 400x.

in gingival samples obtained from the control positive groups with the treated groups. A severe hyperplasia of collagen fibres were observed in the gingival samples obtained from groups 2 and 3. However, the microscopic study revealed a reduction of collagen fibres in gingival samples of the treated rats when compared with gingival samples of the control rats. No fibrotic areas were observed in gingival samples from group 1 (negative con- trol group). Extensive fibrosis is a common finding in gingival samples from groups 2 and 3, however a few number of fibrotic areas were observed in gingival tissue of roxithromycin treated rats (figure 2). Diameter measurements of the epithelial and connective tissues were obtained (figure 3). The measurements observed in roxithromycin treated rats (group 4) were statistically lower than those observed in the GO positive control groups (group 2 and 


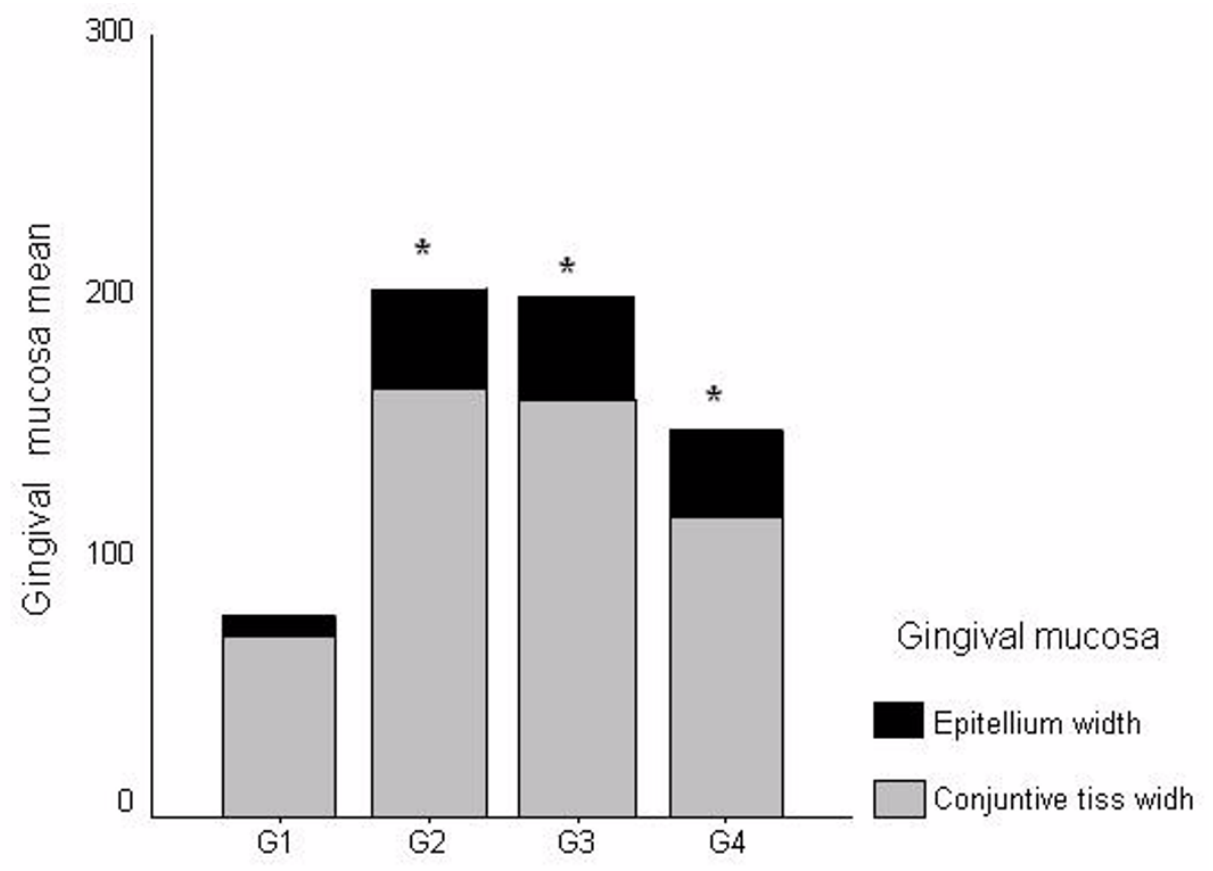

Figure 3

Measurements of gingival mucosa (epithelium and lamina propria). Results expressed as mean $(p<0.05)$. GI $(n=8$ animals) - negative control group - administration of saline solution. $G 2$ ( $n=8$ animals) - positive control group - administration of CsA + saline. G3 ( $n=8$ animals) - positive control group- - administration of CsA + AMP. G4 ( $n=8$ animals) - treated group - administration of CsA + ROX.

group 3). The histomorphometric analysis also demonstrated that the animals treated with roxithromycin presented a lower number of fibroblasts per microscopic field (figure 4). The identification of fibroblasts, based on morphological criteria, was made by two different researchers. Finally, a lower number of inflammatory cells was observed in gingival samples obtained from roxithromycin treated group when compared with group 2 and group 3 (figure 5). Cytoplasmatic staining for TGF-beta2 was detected in most cell types of the connective tissue. TGFbeta2 was expressed within connective tissue by inflammatory cells, fibroblasts and endothelial cells (figure 6). Most of the fibroblasts and endothelial cells were TGFbeta 2 positive and showed a variable staining pattern, usually weakly or darkly positive (figure 6). Immunohistochemical analysis showed a lower number of TGF-beta2 positive cells (figure 7) - recognized morphologically as fibroblasts, endothelial cells and inflammatory cells in the connective tissue samples from roxithromycin treated rats when compared with GO positive controls rats (group 2, and group 3) (figure 7). No significant differences were detected when compared to the number of TGF-beta2 positive cells in gingival samples obtained from group 1 and group 4 (figure 7).

\section{Discussion}

Cyclosporine (CsA) is a hydrophobic neutral cyclic polypeptide composed of eleven amino acids and made from the fungus Tolypocladium inflatuns gams. It specifically acts in suppressing the immune response mediated by $\mathrm{T}$ cells. It goes through biotransformation in the liver, resulting in 14 metabolic products, of which $90 \%$ is excreted in feces and 10\% eliminated by the kidneys [23].

Gingival overgrowth is one of the side effects caused by the chronic use of cyclosporine (CsA), which is employed to prevent rejection of transplanted organs and to treat several autoimmune diseases, such as diabetes mellitus, Behcet's disease, psoriasis, multiple sclerosis, erosive lichen planus, systemic lupus erythematosus, bullous pemphigoid, rheumatoid arthritis, myasthenia gravis, uveitis, and various glomerulopathies $[3,24,25]$.

Several studies have demonstrated elevated levels of specific cytokines in overgrowth gingival tissue, especially TGF-beta, a multifunctional inflammatory mediator, which suggests that this growth factor plays a role in the accumulation of the extracellular matrix $[14,25,26]$, including collagenous proteins $[27,28]$. The TGF-beta isoforms may be expressed by most cells, including gingival 
GROUP 1 - SALINE (negative control) GROUP 2 - CA + saline (postive control) GROUP 3 - CA + AMP (postive control) GROUP 4 - CA + ROX (treated group)

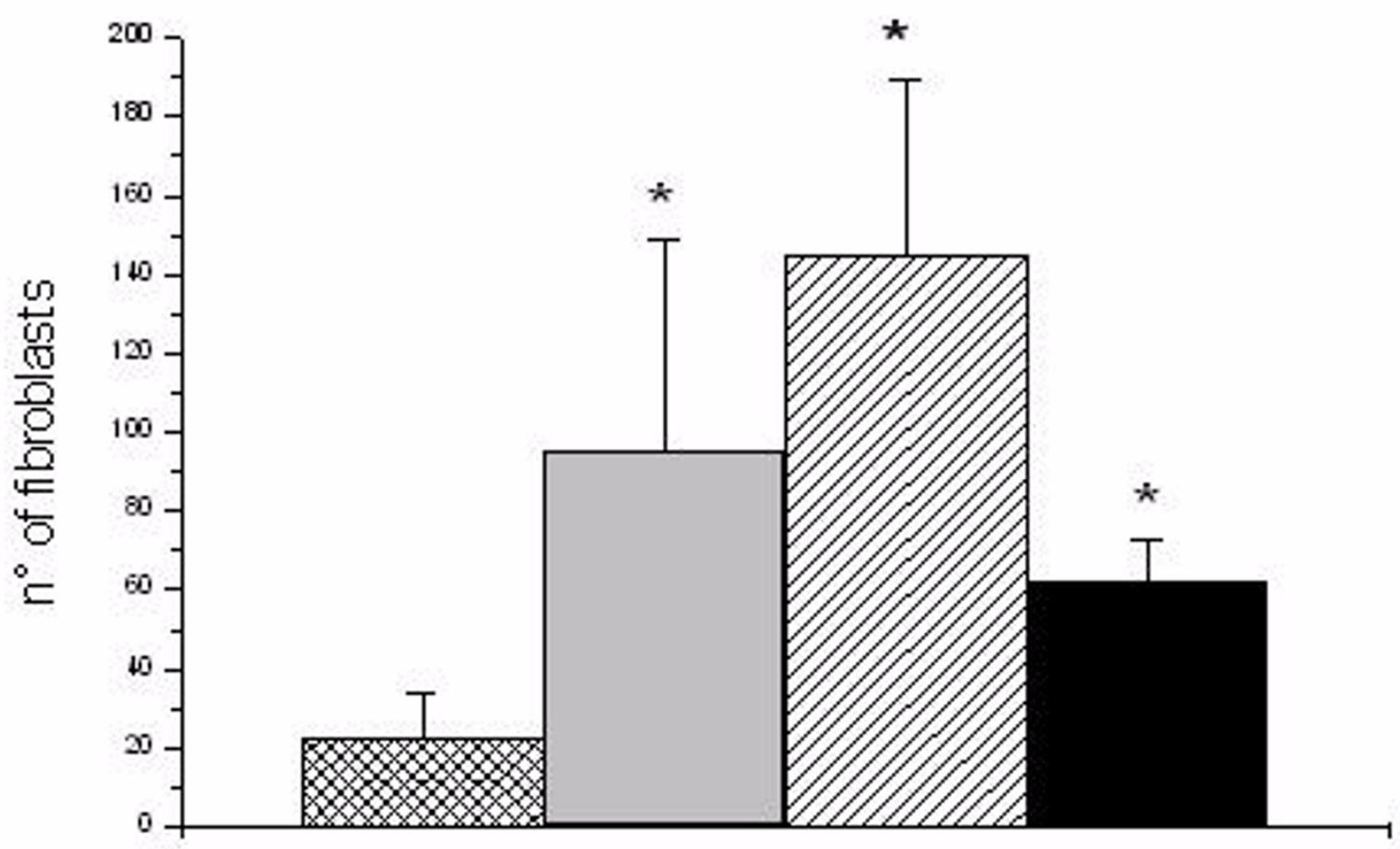

\section{Figure 4}

Numbers of fibroblasts per microscopic fields. Five microscopic fields with $400 \times$ magnification were studied per histological slides. Results expressed as mean $(p<0.05)$. GI $(n=8$ animals) - negative control group - administration of saline solution. $\mathrm{G} 2$ ( $\mathrm{n}=8$ animals) - positive control group - administration of CsA + saline. $\mathrm{G} 3$ ( $\mathrm{n}=8$ animals) - positive control group- administration of CsA + AMP. G4 ( $n=8$ animals) - treated group - administration of CsA + ROX.

inflammatory cells, endothelial cells and fibroblasts [17] Elevated gingival TGF-beta1 and TGF-beta2 have been suggested by immunohistochemical study on phenytoin and nifedipine-induced GO [29]. and our data indicate elevated levels of TGF-beta2 expression on cyclosporininduced GO.

GO treatment includes removing bacterial plaque, maintaining adequate oral hygiene, and also includes invasive procedures, such as gingivectomy. Treatment for this complication, until recently, was only surgical. Nowadays, several studies have been conducted to determine the effect of antibiotic treatment on the regression of gingival overgrowth. In 1995, Wahlstrom, Zamora and Teichmann coincidentally used azithromycin - a semi synthetic antibiotic, derived from the macrolide erythromycin - to treat respiratory infections in two renal transplant patients who had cyclosporine induced GO. They observed gingival reduction after using it. The daily treatment with $500 \mathrm{mg}$ for five days is simple, cheap, conservative, quickly effective, and avoids gingival surgery. It acts mostly against gram-positive and negative bacteria, has quick oral absorption, does not alter serum levels of cyclosporine or levels of creatinine. Azithromycin is well tolerated and associated an efficient oral hygiene program induce a gingival overgrowth reduction [28], but can produce side effects, such as diarrhea, abdominal pain, nausea and vomiting [28-33].

Recently, we used roxithromycin in four renal transplanted patients and the results suggest that roxithromycin may be an important therapeutic tool used to reduce 


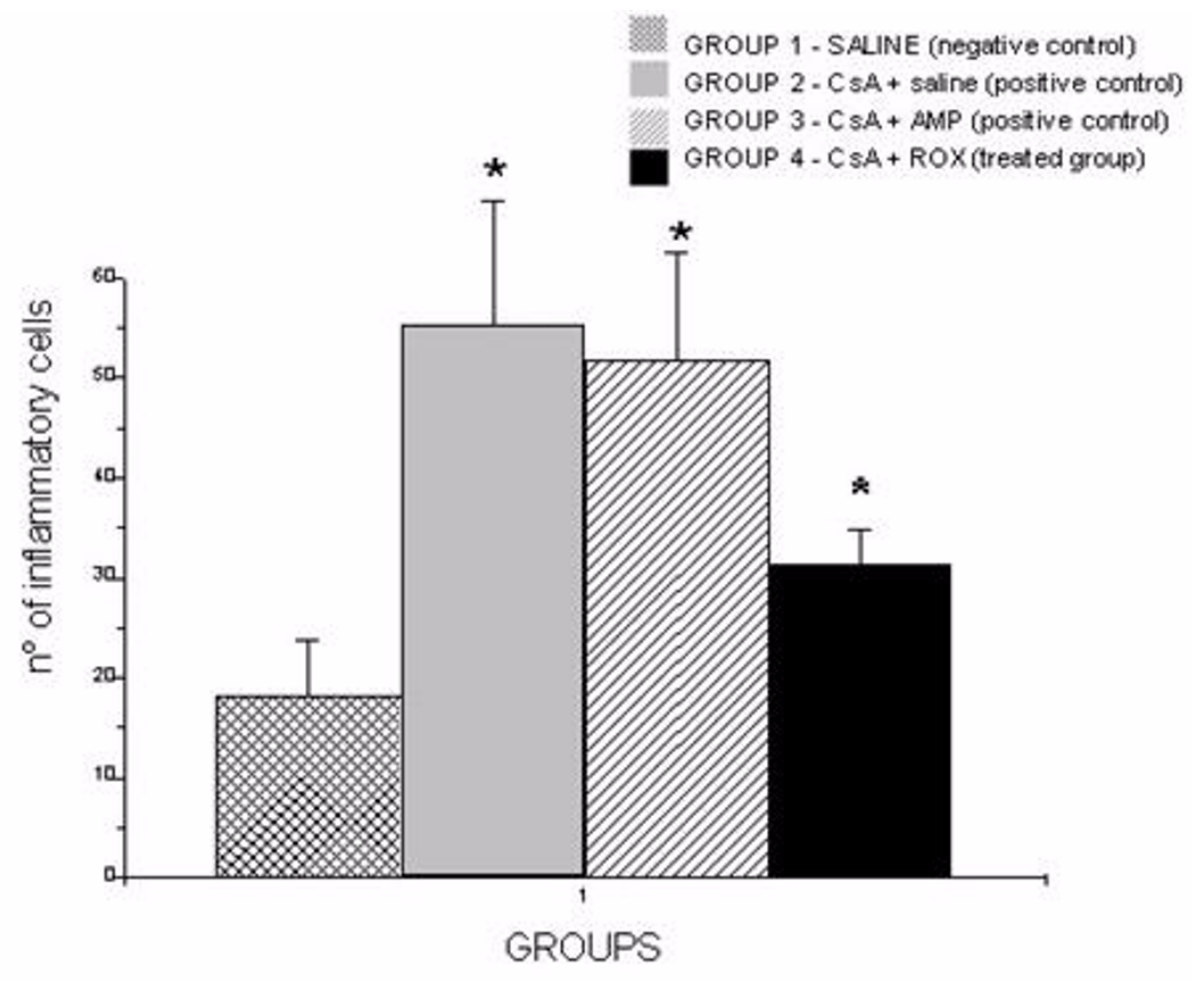

Figure 5

Number of inflammatory cells per microscopic fields. Five microscopic fields with $400 \times$ magnification were studied per histological slides. Results expressed as mean \pm SD ( $p<0.05)$. GI ( $=8$ animals) - negative control group - administration of saline solution. $\mathrm{G} 2$ ( $\mathrm{n}=8$ animals) - positive control group - administration of CsA + saline. $\mathrm{G} 3$ ( $\mathrm{n}=8$ animals) - positive control group- - administration of CsA + AMP. G4 ( $n=8$ animals) - treated group - administration of CsA + ROX
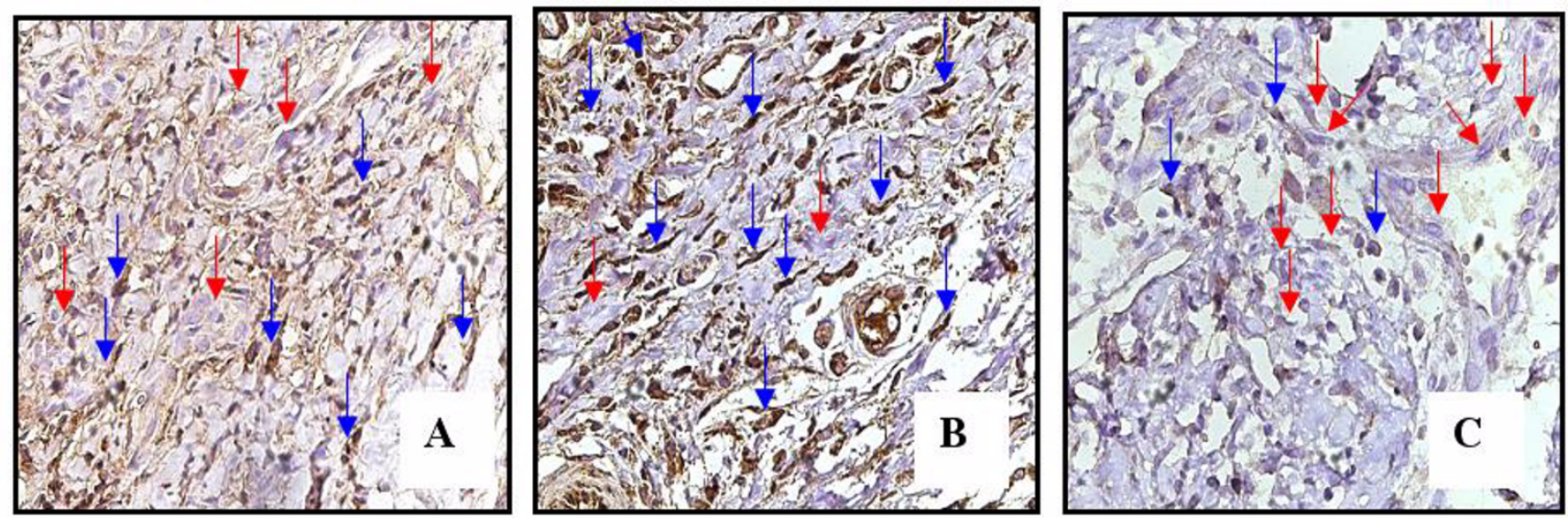

Figure 6

Representative samples indicated elevated expression of TGF-beta2 in cells of connective tissue (groups 2 and 3); C: Light TGF-beta2 stained cells in group 4. Red arrows - negative staining cells. Blue arrows: positive staining cells. Original magnificance $400 x$. 


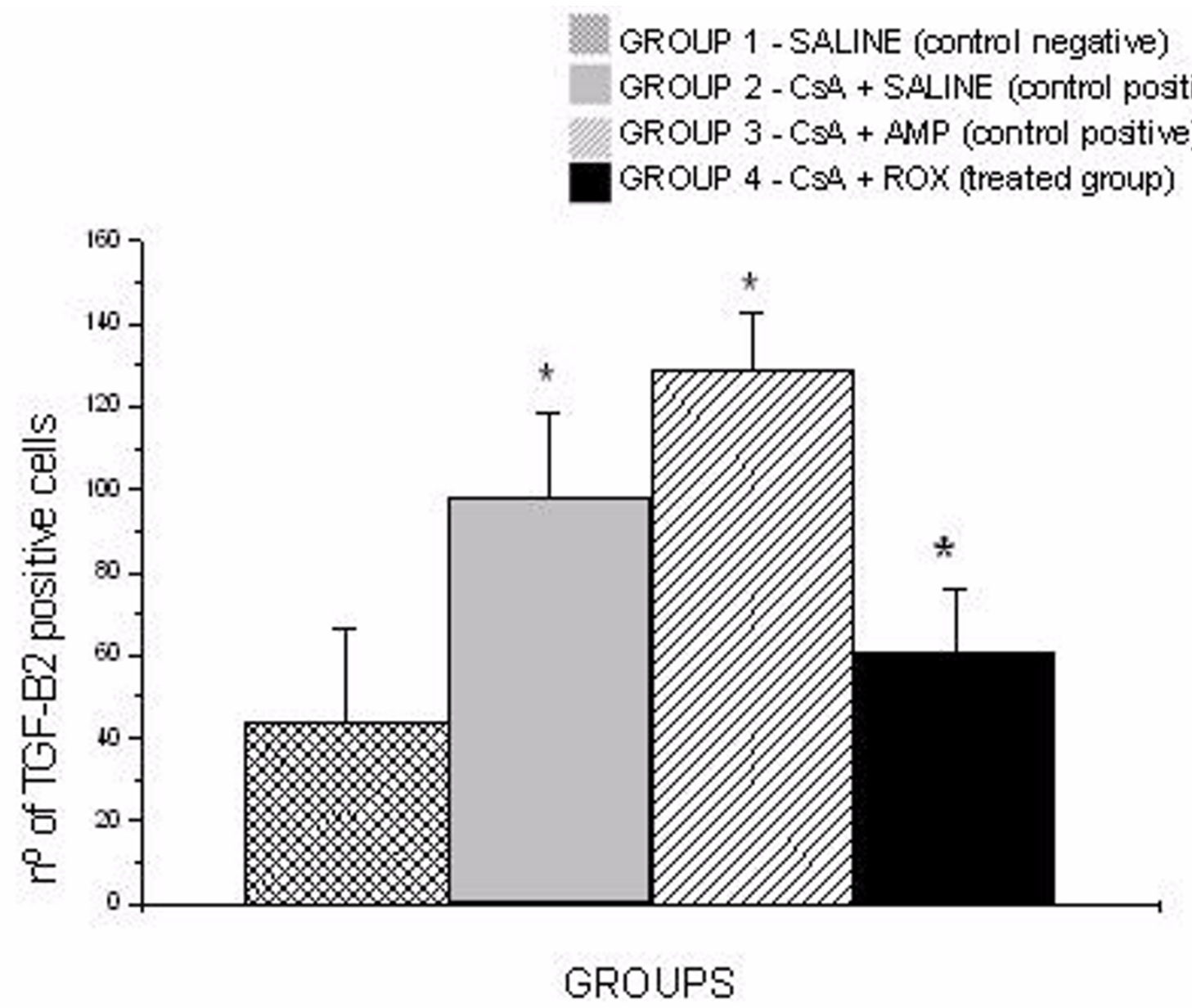

Figure 7

Number of positive staining cells of TGF-beta2 in connective tissue per microscopic field. Five microscopic fields with $400 \times$ magnification were studied per histological slides. Results expressed as mean mean $\pm S D(p<0.05)$. GI $(n=8$ animals) - negative control group - administration of saline solution. $G 2$ ( $n=8$ animals) - positive control group - administration of CsA + saline. G3 ( $n=8$ animals) - positive control group- - administration of CsA + AMP. G4 ( $n=8$ animals) - treated group administration of CsA + ROX.

cyclosporine-induced GO [22]. Yamabe et al. (2006) suggested that the use of roxithromycin has an inhibitory effect on the production of TGF-beta by human mesangial cells, and can be efficient in the treatment of glomerulosclerosis. The mechanisms that roxithromycin inhibited TGF-beta production are not clear, but in this study the drug did not inhibit the activation of tyrosine kinase and MAP kinase by thrombin. Roxithromycin suppressed the thrombin-induced translocation of NF-kB p65 protein into the nucleus. It is suggested that the activation of NF$\mathrm{kB}$ regulates TGF-beta production, thus ROX inhibited TGF-beta production via the inhibition of NF-kB.

\section{Conclusion}

In the present study, the results demonstrated that roxithromycin treatment was effective to reduce cyclosporine- induced GO in rats. Both epithelial and connective tissues showed a decrease in thickness in roxithromycin treated rats in comparison with animals from the control groups. In addition, the significant reduction in TGF- beta2 expression in roxithromycin treated rats was associated with a lower number of fibroblasts, with reduction of fibrotic areas and decrease in inflammatory infiltrate. Taken together, our data suggest that the down-regulation of TGF-beta2 expression may be an important mechanism of action by which roxithromycin inhibits GO.

\section{Abbreviations}

AMP: ampicillin; CsA: ciclosporine; GO: gingival overgrowth; MAP quinase: quinase protein actived by mithogen; NF-kB: nuclear factor kappa B; ROX: roxithromycin; TGF-beta1: transforming growth factor beta1; TGF-beta2: 
transforming growth factor beta2; UFJF: Federal University of Juiz de Fora

\section{Competing interests}

The authors declare that they have no competing interests.

\section{Authors' contributions}

SC have been involved in drafting the manuscript, acquisition and analysis of data and carried out the immunohistochemistry. MB participated in the design of the study and coordination such as performed the statistical analysis. BV analysis and interpretation of data. IM helped in the experimental phase, inducing gingival overgrowth. LV carried out the immunohistochemistry. FA participated in the design of the study and coordination and have given final approval of the version to be published. All authors read and approved the final version of the manuscript.

\section{Acknowledgements}

Financial support: FAPEMIG - Rede Mineira de Toxicologia; Rede Mineira de Bioterismo

\section{References}

I. Rateitschak-Pluss EM, Hefti A, Löertscher R, Thiel G: Initial observation that cyclosporine-A induces gingival enlargement in man. J Clin Periodontol 1983, 10:237-246.

2. Daley TD, Wysocki GP: Cyclosporin therapy. J Periodontol I984, 55:708-7I2.

3. Kahan BD: Cyclosporine. N Engl J Med 1989, 32 I:|725-I738.

4. Seymour RA, Jacobs DJ: Cyclosporin and the gingival tissues. $J$ Clin Periodontol 1992, I 9: I- I I.

5. Wisocki GP, Gretzinger HA, Laupacis A, et al.: Fibrous hyperplasia of gingival: a side effect of cyclosporin-A therapy. Oral Surg Oral Med Oral Pathol 1983, 55:274-278.

6. Daley TD, Wysocki GP, Day C: Clinical and pharmacologic correlations in cyclosporine-induced gingival hyperplasia. Oral Surg Oral Med Oral Path 1986, 62:417-421.

7. Seymour RA, Smith DG, Rogers SR: The comparative effectof azathioprine and cyclosporin on some gingival health parameters of renal transplant patients. J Clin Periodontol 1987, 14:610-613.

8. Wondimu B, Dahllof G, Berg U, et al.: Cyclosporine-A induced gingival overgrowth in renal transplant children. Scand J Dent Res 1993, 101:282-286.

9. Allman SD, Mcwhorter AG, Seale NS: Evaluation of cyclosporine induced gingival overgrowth in the pediatric transplant patient. Pediatr Dent 1994, 16:36-40.

10. Thomason JM, Seymour RA, Rice N: Prevalence and severity of cyclosporine and nifedipine.-induced gingival overgrowth. J Clin Periodontol 1993, 20:37-40.

I I. Bökenkamp A, Bohnhorst B, Beier C, et al.: Nifedipine aggravates cyclosporine-A induced gingival hyperplasia. Pediatr Nephrol 1994:181-185.

12. O'Valle F, Mesa F, Aneiros J, et al.: Gingival overgrowth induced by nifedipine and cyclosporin A. J Clin Periodontol 1995, 22:59I-597.

13. Margiotta V, Pizzo I, Pizzo G, et al.: Cyclosporin-and nifedipineinduced gingival overgrowth in renal transplant patients: correlations with periodontal and pharmacological parameters, and HLA- antigens. J Oral Pathol Med 1996, 25: I28-134.

14. James JA, Irwin CR, Linden GJ: Gingival fibroblast response to cyclosporin $A$ and transforming growth factor beta I. J Periodontol Res 1998, 33:40-48.

I5. Ihn H: Pathogenesis of fibrosis: Role of TGF and CTGF. Curr Opin Rheumatol 2002, I 4:68I-685.

16. Vieira JM Jr, Noronha IL, Malheiros DM, Burdmann EA: Cyclosporine-induced interstitial fibrosis and arteriolar
TGF-beta expression with preserved renal blood flow. Transplantation 1999, 68:1746-1753.

17. Wrigth HJ, Chapple ILC, Matthews JB: TGF- isoforms and TGFreceptors in drug-induced gingival and hereditary gingival overgrowth. J Oral Pathol 2001, 30:281-289.

18. Smith PD, Polo M, Soler PM, McClintock JS, Maggi SP, Kim YJ, Ko F, Robson CM: Efficacy of growth factors in the accelerated closure of interstices in explanted meshed human skin grafts. J Burn Care Rehabil 2000, $21: 5-9$.

19. Saika S: TGF-beta pathobiology in the eye. Lab Invest 2006, 86(2): |06-I|5.

20. Maier P, Broszinski A, Heiznann U, Boehringer D, Reinhard T: Determination of active TGF-2 in aqueous humor prior to and following cryopreservation. Molecular Vision 2006, I 2: |477- 482.

21. Yamabe H, Shimada M, Kaizuka M, Kumasaka R, Murakami R, Fujita T, Nakamura N, Osawa H, Okumura K: Roxithromycin inhibits transforming growth factor- production by cultured human mesangial cells. Nephrology 2006, I I:524-530.

22. Conde SAP, Aarestrup FM, Vieira BJ, Bastos MG: Roxithromycin reduces cyclosporine-induced gingival hyperplasia in renal transplant patients. Transplantation Proceedings 2008 , 40:1435-1438.

23. Seymour RA, Thomason JM, Ellis JS: The pathogenesis of drug induced gingival overgrowth. J Clin Periodontol 1996, 23:165-I75.

24. De Mattos AM, Olyaei AJ, Bennett WM: Pharmacology of immunosuppressive medications used in renal diseases and transplantation. Am J Kidney Dis 1996, 28:631-667.

25. Yoshida T, Nagata J, Yamane A: Growth factors and proliferation of cultured rat gingival cells in response to cyclosporin $A$. J Periodont Res 2005, 40: I I-19.

26. Ruhl S, Hamberger S, Betz R, Sukkar T, Schmalz G, Seymour RA Hiller KA, Thomason JM: Salivary proteins and cytokines in drug-induced gingival overgrowth. J Dent Res 2004, 83(4):322-326

27. Roberts AB, Anzano MA, Meyers CA, Wideman J, Blacher R, Pan YC, Stein S, Lehrman SR, Smith JM, Lamb LC: Purification and properties of a type transforming growth factor from bovine bovine kidney. Biochemistry 1983, 22:5692-5698.

28. Ramalho VL, Ramalho HJ, Cipullo JP, Azoubel R, Burdmann EA: Comparison of azithromycin and oral hygiene program in the treatment of cyclosporin-induced gingival hyperplasia. Ren Fail 2007, 29:265-70.

29. Saito K, Mori S, Iwakura M, Sakamoto S: Immunohistochemical localization of transforming growth factor $b$, basic fibroblast growth factor and heparan sulphate glycosaminoglycan in gingival hyperplasia induced by nifedipine and phenytoin. J Periodont Res 1996, 31:545-555.

30. Wahlstrom E, Zamora JV, Teichman S: Improvement in cyclosporine associated gingival hiperplasia with azithromycin therapy. N Engl J Med I995, 332(I I):753-754.

31. Barnard JÁ, Lyons RM, Moses HL: The cell biology of trasnsforming growth factor-. Biochim Biophys Acta 1990, I032:79-87.

32. Gómez E, Sánchez-Nuñes M, Sánchez JE, Corte C, Aguado S, Portal C, Baltar J, Alvarez-Grande J: Treatment of cyclosporin-induced gingival hyperplasia with azithromycin. Nephrol Dial Transplant 1997, 12:2694-2697.

33. Wirnsberger GH, Pfragner R, Mauric A, Zach R, Bogiatzis A, Holzer $\mathrm{H}$ : Effect of antibiotic treatment azithromycin on cyclosporine Ainduced gingival hyperplasia among renal transplant recipients. Transplant Proc 1998, 30:2 I I7-2119.

\section{Pre-publication history}

The pre-publication history for this paper can be accessed here:

http://www.biomedcentral.com/1472-6831/9/33/prepub 